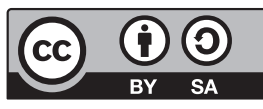

https://doi.org/10.31261/IJREL.2020.6.1.08

\title{
Eugenia Smyrnova-Trybulska
}

University of Silesia in Katowice, Poland https://orcid.org/0000-0003-1227-014X

\section{Dawid Staniek}

University of Silesia in Katowice, Poland https://orcid.org/0000-0001-7909-1934

\section{Dominika Zegzuła}

University of Silesia in Katowice, Poland https://orcid.org/0000-0003-2885-0712

\section{Robotics in Education A Survey Report: Case Study}

\begin{abstract}
This article analyses various aspects of using robotics in education and examines the level of preparation and motivation of children and pupils. The authors carry out a comprehensive review of research and scientific publications regarding technological, didactical, methodological, and human aspects of using robotics in education. The article presents a report on a survey on pupils' opinion on robotics in education, which was conducted during the third Silesian Science Festival, and discusses the exhibition stand presenting innovative digital technologies and methods in education and business as well as Photon robots.
\end{abstract}

K e y w o r d s: robots, educational robots, robotics in education, STEM education, survey 
Programming and educational robots - elements of teaching implemented in accordance with the new core curriculum - start from early school education and thus require teachers and other people working with children and young people to improve the methodology of teaching this area of knowledge. The new detailed content on algorithmics and programming introduced to the core curriculum has become a novelty also for teachers (Bobko, Bubula, Marek, Sala, \& Wójciak, 2018 , p. 7). This has also confirmed earlier Research (Smyrnova-Trybulska, Morze, Kommers, Zuziak, \& Gladun, 2017). Additionally, "robots are slowly being incorporated in our society and the number of service robots has in 2008 already outnumbered industrial robots (IFR, 2008). Robots are slowly beginning a process of seamless integration in everyday lives both at home and at school. This impact of social robotics is even more crucial for children and teenagers, where robots can be used for their development and intellectual growth" (Mubin, Stevens, Shahid, Mahmud, \& Dong, 2013, p. 1). It is also very important that comprehensive research should continue into various aspects of using robotics in education and the children's and pupils' level of preparation and motivation should continue to be studied.

The article presents the results of a survey carried out among participants of the third Silesian Science Festival 2019. The data were obtained from those individuals who attended workshops and visited the exhibition stand presenting innovative digital technologies in education and business, organised by the Department of Humanistic Education and Auxiliary Sciences of Pedagogy of the Faculty of Ethnology and Sciences of Education at the University of Silesia in Cieszyn, Poland. The respondents aged 6-15 included primary school pupils.

The aim of the survey was to measure interest in the Photon educational robot among primary school pupils and thus in the topic of programming. Particular attention was paid to the availability of this robot or a similar one in the school environment, the desire to have such a device at home and the awareness of the robot's usefulness in development and learning.

\section{Background. Examples of Robotics in Education}

"Educational Robotics (ER) has revealed several benefits in the educational context, not only helping the teaching of disciplines, but also making possible the development of several abilities, such as teamwork, problem-solving, and creativity. Among various robotics kits, $\mathrm{LEGO}^{\circledR}$ Robotics has shown one of the best results considering some evaluated criteria (modularity level, hardware, cur- 
riculum, price, etc.). Some studies analyse the teaching practices, some compare technologies, and others evaluate the kits in a pedagogical way. However, it is essential to investigate all these contexts together in order to improve the impact produced by the ER in education and to know the best teaching practices associated with the most powerful technologies" (Souza, Andrade, Sampaio, \& Araujoy, 2018, p. 1). Using LEGO $^{\circledR}$ Robotics in educational process was described, studied, and analysed in articles by Smyrnova-Trybulska, Morze, Zuziak, and Gladun (2016), while designing and programming robots in schools was discussed by Zuziak (2013).

"Lego Mindstorms robots have been subject to many research studies in the last two decades. Most of this research discuss advantage and disadvantage of using Lego Mindstorms robots as educational tool in a wide range of subjects such as computer science (Cliburn, 2006), engineering (Khalaf, Balawi, Hitt, \& Radaideh, 2010), computer programming (Cliburn, 2006; Ewert, Schilberg, \& Jeschke, 2013), mechatronics (Tokuyasu, 2007), artificial intelligence (Klassner, 2002), etc. Furthermore, robots can be integrated in course curricula at all levels of education; from elementary school (Hixon, 2007) to university level (Cliburn, 2006; Khalaf et al., 2010; Tokuyasu, 2007; Klassner, 2002)" (Zaharija, Granić, \& Grubač, 2014, p. 209).

Various ways using of Robotics in Education have been discussed in numerous publications. "Robotics in Education (R-in-E) tries to strengthen the learning skills of future engineers and scientists by means of robot-based projects. Both at school and in college, presenting robots in the classroom will give students a more interesting (and fun) vision of science and engineering, and they will be able to observe directly the practical application of theoretical concepts in the fields of mathematics and technology. R-in-E is inclusive in nature, which can lead students to orient their university studies in fields related to the STEM subjects" (Curto \& Moreno, 2016, p. 3).

The American researchers Lixiao Huang, Terri Varnado, and Douglas Gillan (2013) in their study stressed that "this research explored the emotional attachment that students might develop towards robots that they built in a 2-month period, as well as the factors that contributed to their emotions towards the robots. The research studied 16 students enrolled in the robotics class in the fall 2012 semester who completed a specially-designed questionnaire. The results showed that students had strong positive emotions towards their robots" (Huang, Varnado, \& Gillan, 2013, p. 1825).

In another research the authors focus on the following: Allan Zollman wrote about STEM literacy: "a general consensus that everyone needs to be STEM literate. But there is a difference between literacy and being literate. STEM literacy should not be viewed as a content area but as a deictic means (composed of skills, 
abilities, factual knowledge, procedures, concepts, and metacognitive capacities) to gain further learning" (Zollman, 2012, p. 12). The author in his research provided a "brief background of literacy definitions in STEM and present[ed] a description of STEM literacy based upon (1) cognitive, (2) affective, and (3) psychomotor learning theory domains. The paper stress[ed] the need to evolve from learning for STEM literacy to using STEM literacy for learning to satisfy our societal, economic, and personal needs" (Zollman, 2012, p. 12).

Anne Jolly (2014) developed and described six characteristics of a great STEM lesson:

1. STEM lessons focus on real-world issues and problems. [...]

2. STEM lessons are guided by the engineering design process. [...]

3. STEM lessons immerse students in hands-on inquiry and open-ended exploration. [...]

4. STEM lessons involve students in productive teamwork. [...]

5. STEM lessons apply rigorous math and science content your students are learning. [...]

6. STEM lessons allow for multiple right answers and reframe failure as a necessary part of learning. (Jolly, 2014)

Based on her recent research, five trends were identified in Technology Education (Figure 1).

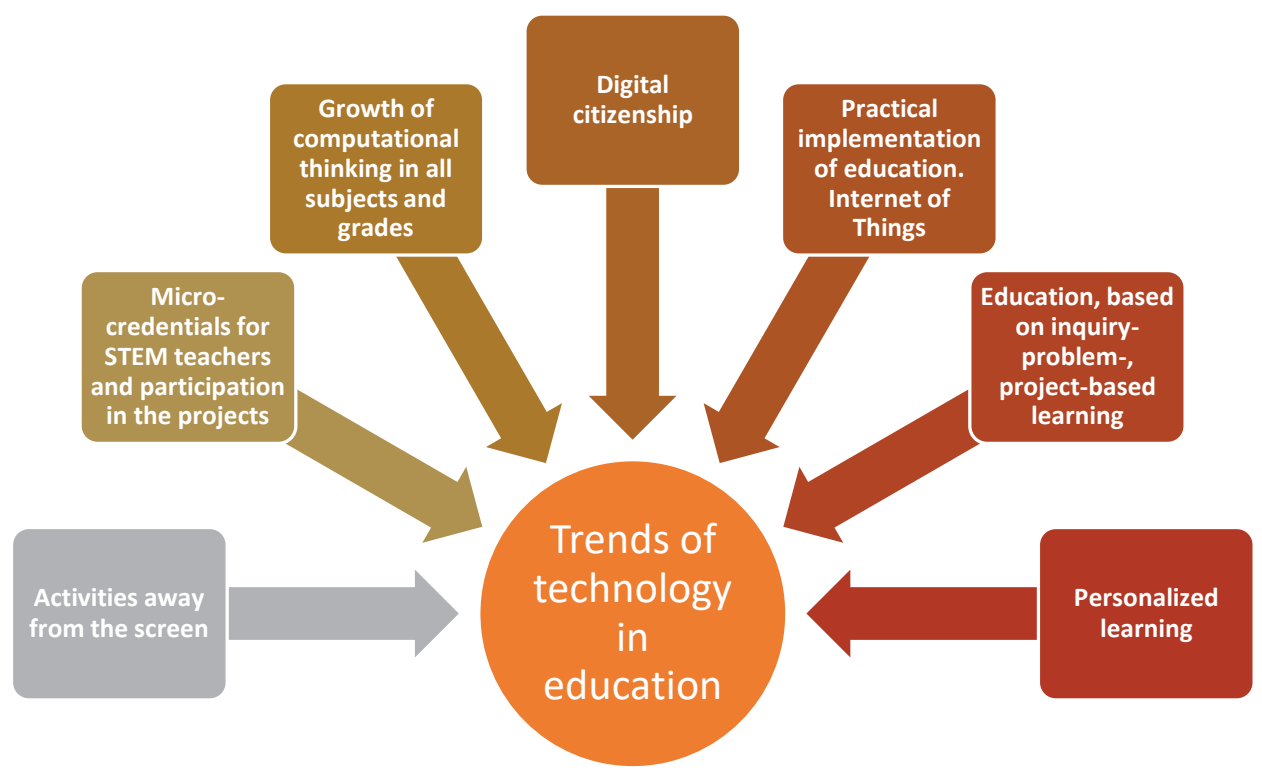

Figure 1. Trends of technology in education.

Source: Authors' own work based on Mo Qureshi (2019)

IJREL.2020.6.1.08 p. $4 / 18$ 
Other authors Borys Crnokić, Miroslav Grubišić, and Tomislav Volarić presented "different possibilities of using mobile robots in education. Through the application of the mobile mechatronic robotic system Robotino researchers show the possibilities of developing interactive lectures and exercises in order to raise the quality of education and to provide new competencies for students. The application of a robot as a real system supports strengthening specific areas of knowledge and skills that the students develop through design, creation, assembly, and operating with the robot. This way of learning contains a very important element and that is 'layful learning' or learning through play. Along with technical competences, combining this method with teamwork improves also social skills and motivation for learning [...]" (Crnokić, Grubišić, \& Volarić, 2017, p. 15). The authors "present an application of the robot in education on examples of modelling and designing of mechatronic systems, simulating and parameters monitoring the mechatronic systems, and collecting, processing and application of data from sensors in mechatronic systems" (Crnokić, Grubišić, \& Volarić, 2017, p.15).

Researchers Tony Belpaeme, James Kennedy, Aditi Ramachandran, Brian Scassellati, and Fumihide Tanaka, focus on social robots for education study. They particularly stressed that "social robots can be used in education as tutors or peer learners. They have been shown to be effective in increasing cognitive and affective outcomes and have achieved outcomes similar to those of human tutoring on restricted tasks. This is largely because of their physical presence which traditional learning technologies lack" (Belpaeme, Kennedy, Ramachandran, Scassellati, \& Tanaka, 2018, p. 1).

\section{Some Aspects of Using Robots in Education}

Active implementation of robotics and programming during school lessons, carried out on the basis of a demanding core curriculum, requires the teacher to properly select the equipment sets on which she/he wants to base her/his classes. Among the basic criteria that such a set should meet is, which is definitely worth highlighting, access to a friendly programming environment that allows students to easily, and in stages, explore the secrets of cooperation with the robot. In the perspective of longer work, it also becomes important to choose such a set that enables independent expansion and the expansion of interaction options. Everyone, even the most passionate robot at the beginning, loses its attractiveness as students' skills increase. The development of mobile technologies means that mobile devices (e.g., smartphones, tablets) are being increasingly used for operation and programming. 
Considering their convenience, small requirements for access to a constant power source, as well as their universality (students have their own equipment, which means that there is no need to make additional purchases), it becomes possible to conduct robotics classes, for example, during a school trip or outdoors. It is also extremely important to choose a device with such level of sophistication so as not to discourage students from using it.

When deciding on a specific model of an educational robot for children whose first contact with robotics is to be based on this device, the teacher should apply the principle of small steps. Authors (Mubin, Stevens, Shahid, Mahmud, \& Dong, 2013) developed their proposal for classification of robots and thus presented a "choice of robots across subject domains and across background knowledge required in computing (the darker the colour, the more computing knowledge is required to use/interact with the robot in that cell)" (p. 4) according to a subject type, that is, an electronic robotic kit, a mechanical robotic kit, and a humanoid robot (p. 4). We agree with the authors that we do not intend that robots should replace human teachers but highlight the added value that robots can bring to the classroom in the form of a stimulating, engaging, and instructive teaching aid. Table 1 presents an overview of robots for use in education, taking into account several basic criteria: set name, company manufacturer, website address, level of advancement, dedicated software, and development options.

Table 1

An overview of robots for use in education

\begin{tabular}{|c|c|c|c|c|}
\hline $\begin{array}{l}\text { Name } \\
\text { of the set }\end{array}$ & $\begin{array}{l}\text { Expanda- } \\
\text { bility }\end{array}$ & $\begin{array}{l}\text { Dedicated } \\
\text { software }\end{array}$ & $\begin{array}{l}\text { Level of } \\
\text { advancement }\end{array}$ & $\begin{array}{l}\text { Company producer } \\
\text { Website }\end{array}$ \\
\hline LoFi Robot & Big & NO & Intermediate & $\begin{array}{l}\text { LOFI Sp. z o.o. } \\
\text { https://www.lofirobot.com/ }\end{array}$ \\
\hline $\begin{array}{l}\text { Makeblock } \\
\text { Mbot }\end{array}$ & Average & YES & Intermediate & $\begin{array}{l}\text { Makeblock Co., Ltd } \\
\text { https://www.makeblock.com/ }\end{array}$ \\
\hline Ozobot & Small & YES & Beginner & $\begin{array}{l}\text { EduSense Sp. z o.o. } \\
\text { http://www.ozobot.pl/ }\end{array}$ \\
\hline $\begin{array}{l}\text { Lego } \\
\text { Mindstorm }\end{array}$ & Big & YES & Full & $\begin{array}{l}\text { Lego Group } \\
\text { https://www.lego.com/pl-pl/ } \\
\text { mindstorms }\end{array}$ \\
\hline Dash and Dot & Small & YES & Beginner & $\begin{array}{l}\text { Wonder Polska Sp. z o.o. Sp. k. } \\
\text { http://makewonder.pl/ }\end{array}$ \\
\hline Photon & Small & YES & Full & $\begin{array}{l}\text { Photon Entertainment sp. z o.o. } \\
\text { https://photonrobot. } \\
\text { com/pl/ }\end{array}$ \\
\hline
\end{tabular}

S ou r c e: Authors' own work

IJREL.2020.6.1.08 p. $6 / 18$ 
The robot has been created for children of all ages. Its service is adapted to various stages of children's development, their abilities and perception abilities. Applications have as many as four interfaces that enable diversity learning for both pre-school children and children from 5 to 12 years of age (https://photonrobot. $\mathrm{com} / \mathrm{pl})$.

The Photon robot, which was the subject of interest of the surveyed children, is an interactive educational toy. The robot is integrated with a dedicated application for any mobile device (smartphone or tablet). The main advantage of Photon is learning the basics of programming and using its capabilities to support the learning of other subjects (e.g., a foreign language). The producers' assumption is to tame school children with new technologies in education. Develop their creativity, logical thinking, and overall development. It is intended for children from preschool to 12 years old. It is worth noting that the Photon robot is a Polish product (https://photonrobot.com/pl/). The Photon robot is an interactive educational robot that introduces children to the world of new technologies through a mobile application and related experiences and experiments. Photon supports children in developing the basic skills of our time. It helps them develop creativity, the ability to think logically, learn the basics of programming and understand the operation of the sensors it is equipped with.

The robot develops with the child. Photon is designed for independent and individual learning at home, where the child develops his/her robot. All tasks and experiments are based on a story in the application, in which the user helps Photon to overcome new challenges while learning the basics of programming and logical thinking. Photon's skills are closely dependent on the child's progress. When we take the robot out of the box [...] it cannot do anything at all. Children must help it learn everything from scratch - how to move, what colours we have, how to react to the environment with the sensors in which the robot is equipped.

\section{Research Results}

The study was conducted on the basis of a questionnaire distributed among 69 children, which provided the basis for this analysis. The questionnaire contains six questions, including an open one indicating the age of the respondents (Q 1 . How old are you?...), one closed multiple choice question determining the sex of the respondents (Q2. Boy/girl). Both questions are important enough to determine the percentage distribution and the relationship between age and gender and interest in the experimental object. Four single-choice closed questions directly 
related to those respondents' interaction and opinions on the Photon educational robot who ended the fun immediately before the survey, which was important for the research results.

Q3. Why did you find the educational robot fascinating?

a) I liked it visually and I want it to be my friend.

b) It evokes positive emotions and a sense of happiness in me.

c) I have long wanted to get to know it better and learn how to control it.

d) I have long wanted to get to know it better and learn to program it.

e) I think that it will be useful for me for further development and learning.

f) Other

Q4. Do you have contact with robots in school/kindergarten?

a) yes

b) no

Q5. Would you like to have a robot at home and play/learn with it?
a) yes
b) no

Q6. If YES, then how often:
a) once a month
b) once a week
c) every day (how many hours?

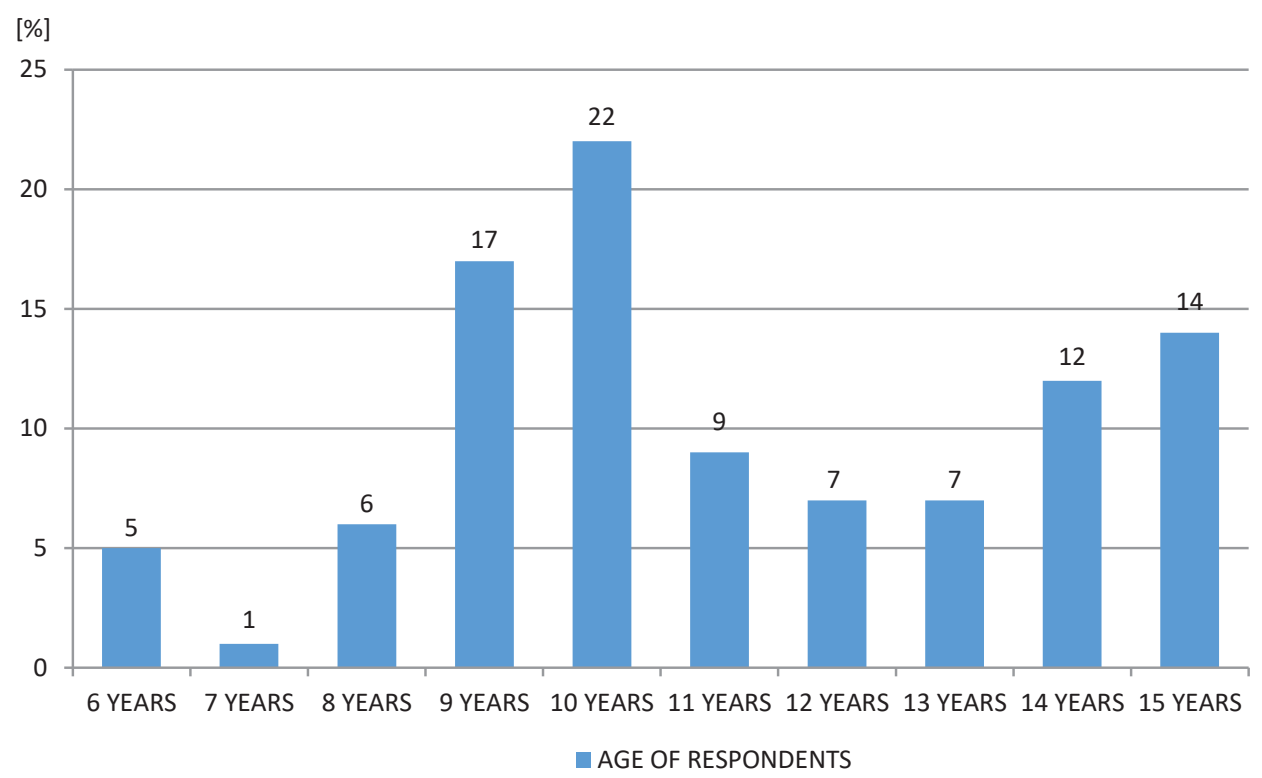

Figure 2. Percentage distribution of the children surveyed by age.

S o u r c e: Authors' own work. 
The group of respondents were children from 6 to 15 years old, with the most numerous group at the age of nine (12 children, which accounted for $17 \%$ of the number of respondents) and ten years (15 children, which accounted for $22 \%$ of the number of respondents). Three children at the age of six responded to the survey, which constituted $5 \%$ of the respondents, one child at the age of seven $(1 \%)$, four children at the age of eight (6\%), six children at the age of $11(9 \%)$, five children aged 12 and 13 (7\%). Considering the size of the group, as many as eight answers were obtained from 14-year-old children (12\%) and ten answers from 15-year-old children (14\%). Data are presented in Figure 2.

The percentage distribution of the study group by gender (Figure 3 ) indicates an almost even number of both 33 boys and 36 girls, which gives a percentage ratio of $52 \%$ girls to $48 \%$ boys.

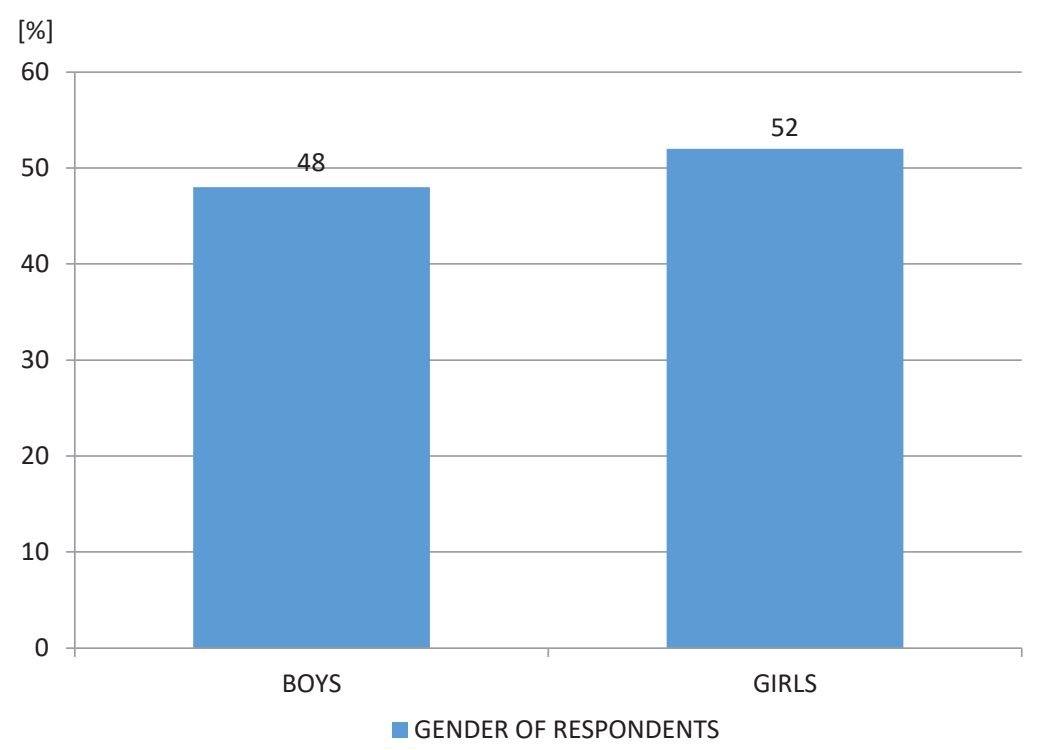

Figure 3. Percentage distribution of the children surveyed by gender.

S o u r c e: Authors' own work.

In the third question, the surveyed children were asked to indicate the reason for their interest in the educational robot. The question was closed with multiple choice. The results of the question were analysed in two ways: the blue line indicates generally the answers given, where the reference point is the number of answers given. The red line indicates the percentage ratio of the number of responses to the number of respondents. The reference point here is the number of respondents. Most, 26 students (38\% of the responses), indicated that they liked the robot because it is visually pleasant. Not much less, seventeen children $(25 \%$ 
of the responses), talked about positive emotions towards the robot. Eleven children ( $16 \%$ of the answers) already knew the robot and wanted to learn to control it. Thirteen children (19\% of the answers) already knew the robot before and had information that the robot was used to learn programming and expressed willingness to learn. A large number of 20 students ( $29 \%$ of the responses) thought that the work could be used to learn or develop their own interests. Two children (3\%) said that controlling the robots is pleasant. The data are shown in Figure 4. Taking into consideration the summary of the percentage ratio of answers given to the number of respondents, the most common answer among children is also answer (a) indicating the visual qualities of the Photon robot (29\%), whereas slightly lesser number of children (23\%) indicated answer (e) appreciating the educational functions of the device. Indications for the answers from the following points do not differ much in percentage: $19 \%$ of the students thought that the robot evokes positive emotions, $12 \%$ of the students were already familiar with the robot and wanted to learn to control it, while $15 \%$ showed a desire to learn programming.

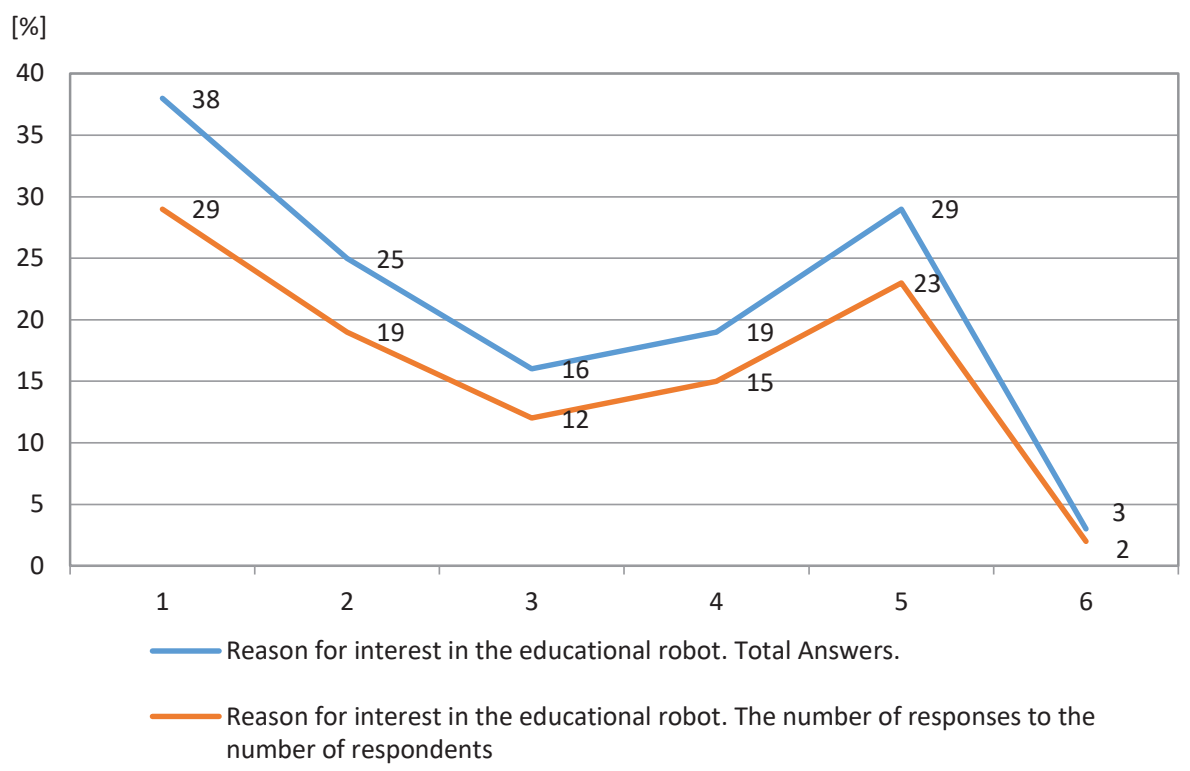

Figure 4. Percentage distribution of answers to the reason for interest in the educational robot.

1 - a) I liked it visually and I want him to be my friend; 2 - b) It evokes positive emotions and a sense of happiness in me; $3-\mathrm{c}$ ) I have long wanted to get to know it better and learn how to control it; $4-$ d) I have long wanted to get to know it better and learn to program it; $5-\mathrm{e}$ ) I think that it will be useful for me for further development and learning; $6-\mathrm{f}$ ) Other S o u r c e: Authors' own work 
An important part of the study was obtaining information on the availability of Photon or other similar robots in the school or kindergarten environment. Twenty-four children said they had the option of using a robot at school (52\%). On the other hand, a large majority of 45 children said they did not have such an opportunity, which constituted as many as $65 \%$ of the respondents (Figure 5).

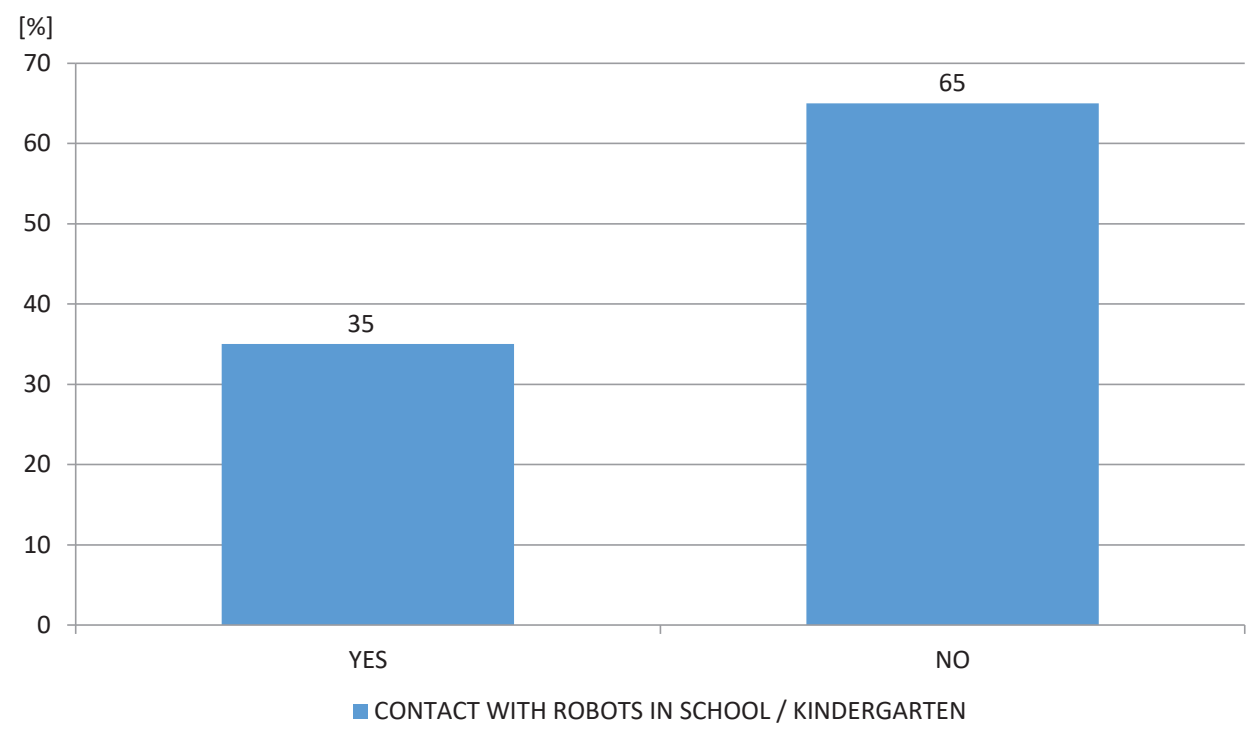

Figure 5. Percentage distribution of answers regarding children's contact with robots at school or kindergarten.

S o u r c e: Authors' own work.

As Figure 6 shows, the robot has attracted the children's interest. When the children were asked whether would like to have Photon at home, as many as 62 children confirmed $(90 \%)$. And only seven children stated that they would not like to have Photon at home (10\%). The information depicted in Figure 6 indicates the percentage distribution of affirmative answers given about the desire to have an educational robot at home and the potential frequency of using the robot. Ten children ( $25 \%$ of affirmative answers to question 5) said they could use the educational robot almost around the clock. Eight children (20\%) could not say how much time a day they would like to use the robot and could use it for two hours a day. The remaining answers are at a comparable level of three to five percent of those surveyed for a specific time period, that is, from half an hour to 4 hours, 10 hours, 12 hours, 16 hours, and 23 hours a day. The exception is the time of one hour, which was indicated by five children, therefore $12 \%$ of the respondents (Figure 7). 


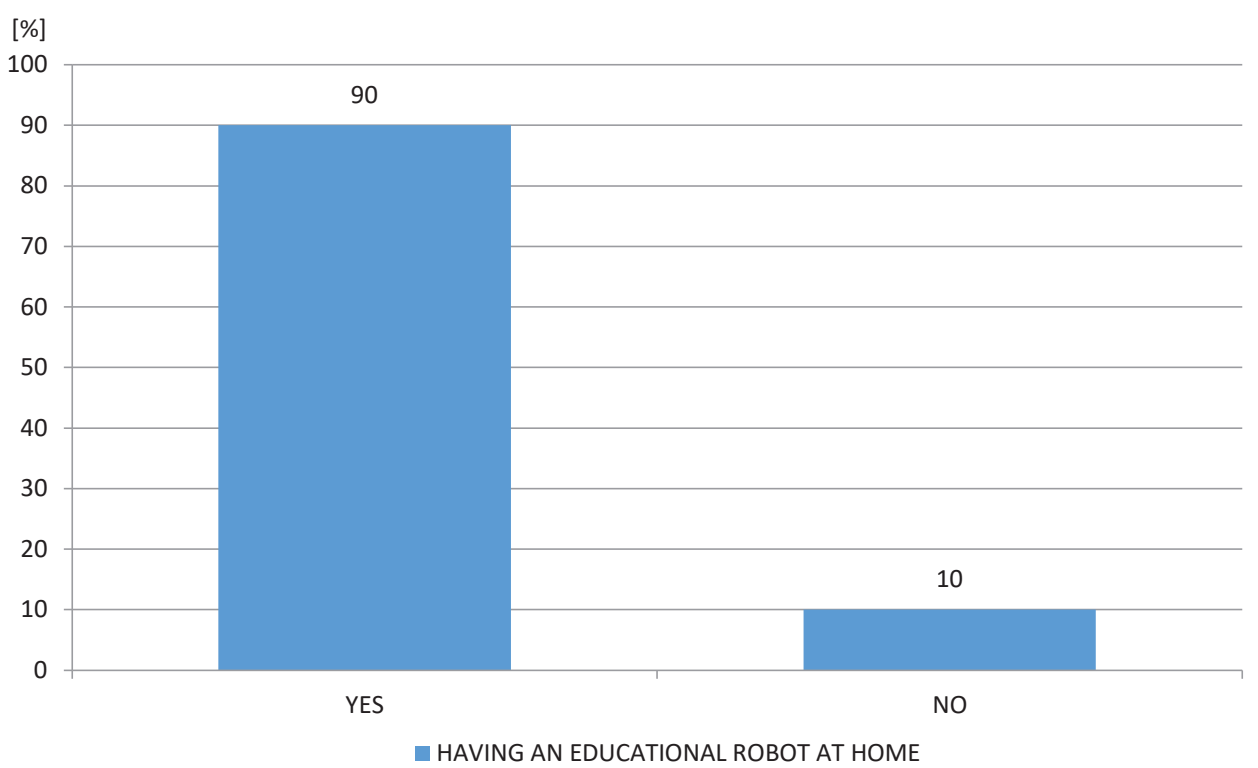

Figure 6. Percentage distribution of answers given about the desire to have an educational robot at home.

S o u r c e: Authors' own work.

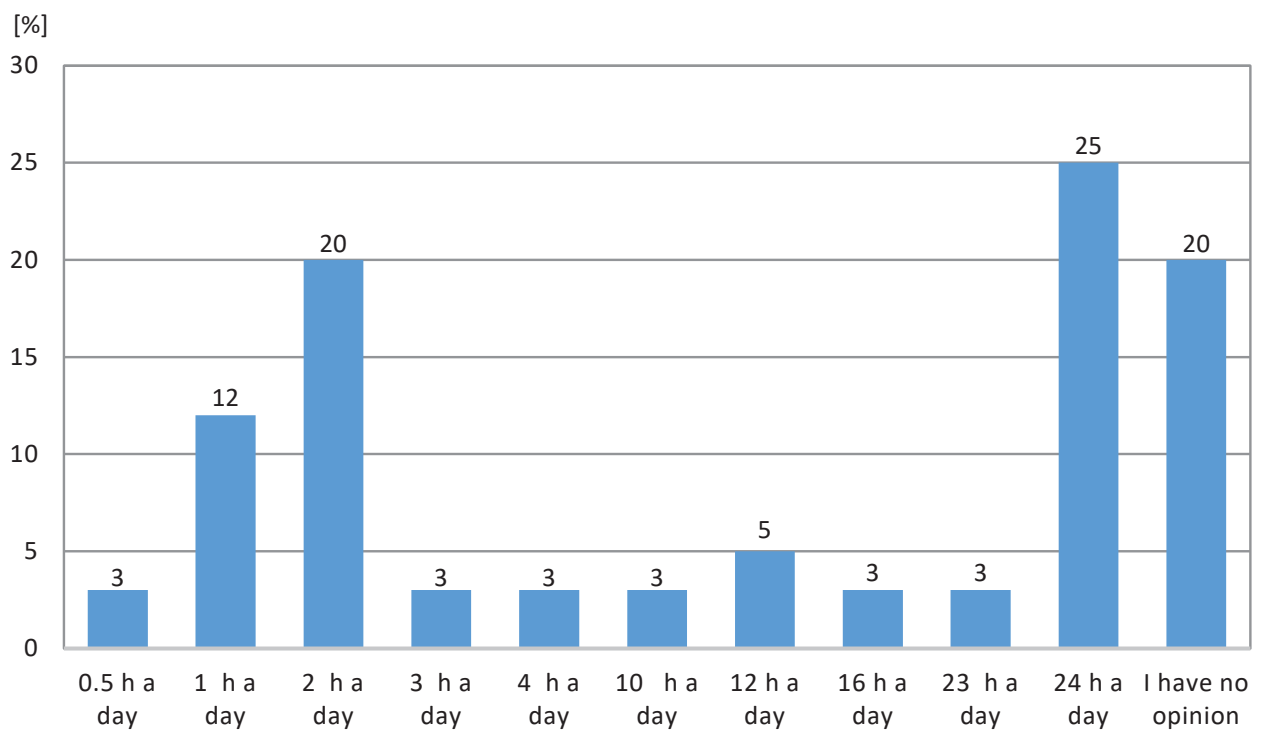

Figure 7. Percentage distribution of affirmative answers given about the desire to have an educational robot at home. Frequency of use.

S o u r c e: Authors' own work

IJREL.2020.6.1.08 p. 12/18 
The results of statistical analyses of the responses have been presented below. Table 2 includes the descriptive statistics. Table 3 shows the comparison of MannWhitney test of age with the answers given to question 6 .

Table 2.

Descriptive statistics

\begin{tabular}{llrrrr}
\hline \multirow{2}{*}{ Variable } & \multicolumn{5}{c}{$\begin{array}{c}\text { Aggregated results descriptive statistics } \\
\text { (empirical data ROBOTS (3) -all) }\end{array}$} \\
& GENDER & N valid & Median & Minimum & Maximum \\
\hline AGE & BOY & 33 & $\mathbf{9 . 0 0 0 0}$ & 6.0000 & 10.0000 \\
QUESTION 6 & BOY & 33 & B & A & C \\
AGE & GIRL & 36 & 13.5000 & 10.0000 & 15.0000 \\
QUESTION 6 & GIRL & 36 & C & C & C \\
\hline
\end{tabular}

Table 3.

A comparison of the Mann-Whitney test of age with the answers to question 6

\begin{tabular}{lcccc}
\hline \multirow{3}{*}{ Variable } & \multicolumn{2}{c}{$\begin{array}{c}\text { Mann-Whitney U test (with continuity correction) } \\
\text { (empirical data ROBOTS (3)-all) } \\
\text { Relative to variable: GENDER }\end{array}$} \\
& \begin{tabular}{c} 
The marked results are significant from $p<.05000$ \\
\cline { 2 - 5 }
\end{tabular} & $\begin{array}{c}\text { N valid. } \\
\text { BOY }\end{array}$ & $\begin{array}{c}\text { N valid. } \\
\text { GIRL }\end{array}$ & $\mathrm{p}$ \\
\hline AGE & 33 & 36 & 0.000000 \\
QUESTION 6 & 33 & 36 & 0.000000 \\
\hline
\end{tabular}

There are significant differences in age between sexes $(\mathrm{p}<0.0001)$. Girls' age is higher and there are significant differences in providing answers to question 6 $(\mathrm{p}<0.0001)$, namely, girls chose $\mathrm{c}$ (every day) whereas boys chose answer $\mathrm{b}$ (once a week) (see Figures 8 and 9). 
Eugenia Smyrnova-Trybulska, Dawid Staniek, Dominika Zegzuła

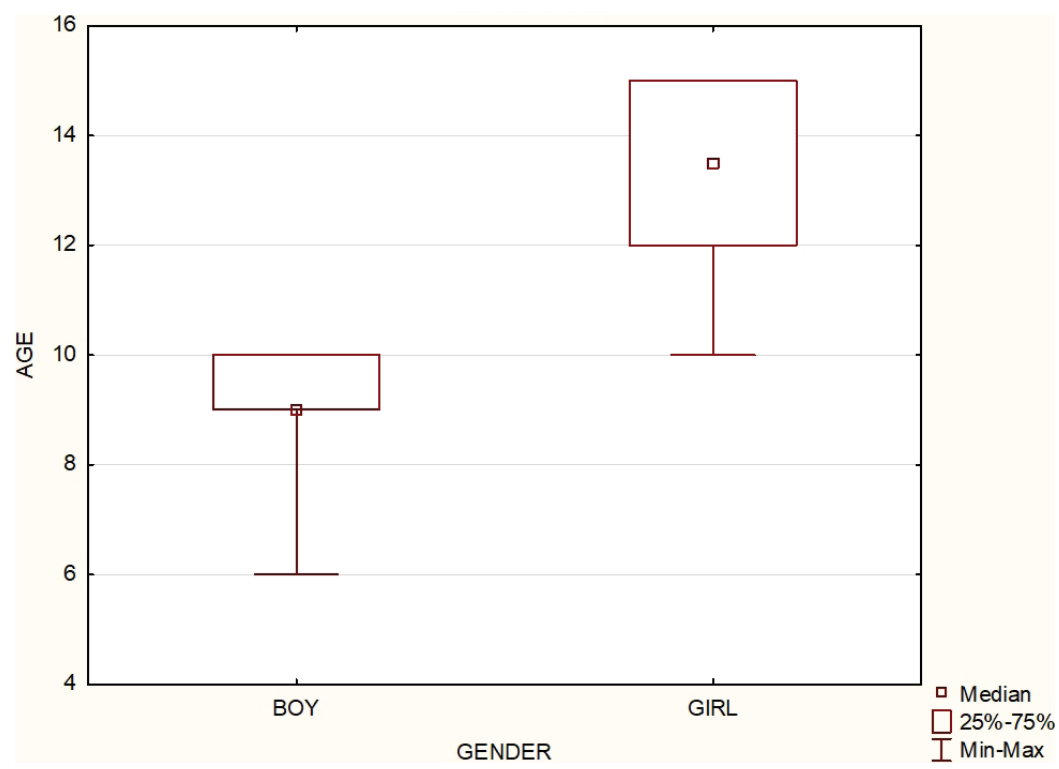

Figure 8.

Age variable.

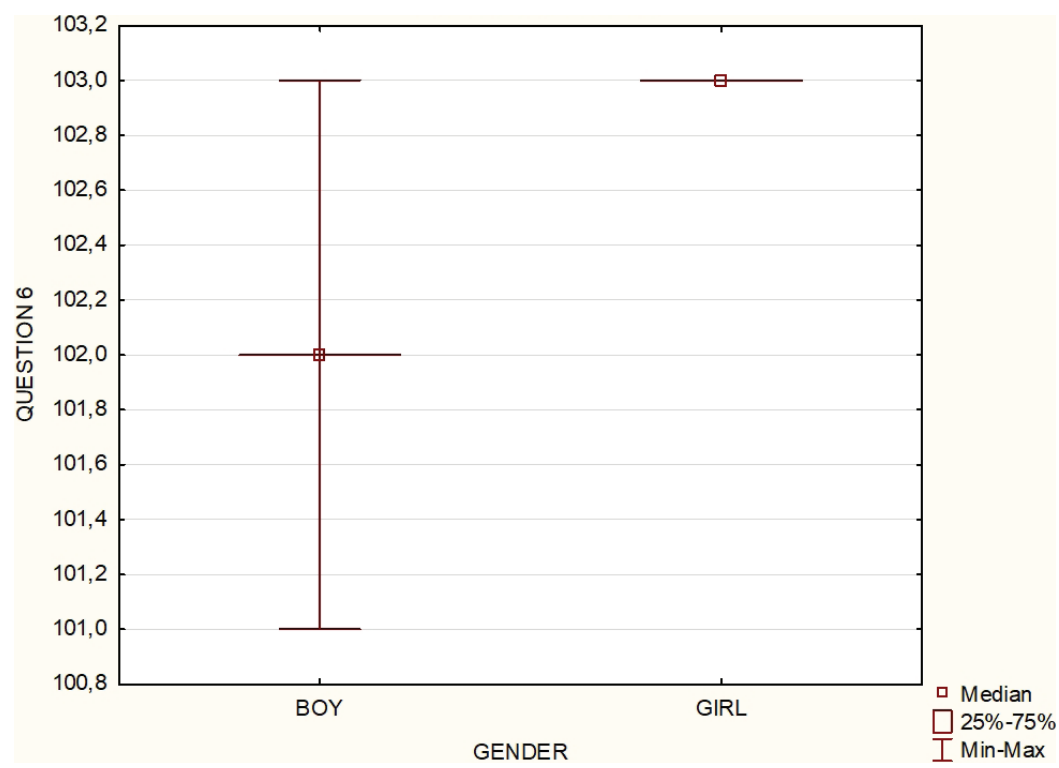

Figure 9.

Variable: Question 6.

IJREL.2020.6.1.08 p. 14/18 


\section{Conclusions}

When paying attention to a large group of children who would like to have a Photon robot at home, it can be argued that the educational Photon is an attractive device for children. As the above data shows, children appreciate not only the visual qualities but, above all, the basic ability of the device such as learning programming and support for general development. Children familiar with the subject of programming could eagerly use it as a tool for further development or help in learning. Beginners, on the other hand, also appreciate the educational possibilities of a robot or object for a pleasant pastime. It is puzzling, however, that a very small percentage of children have the opportunity to interact with this or similar device in the school environment.

Research analysis shows that considerable interest the respondents showed in relation to the Photon robot could be ascribed to the quality of knowledge acquired by students during classes. Therefore, it is worth considering the possibilities of implementing educational robots in the didactic process in primary schools, and the fun elements that undoubtedly allow the robot to skilfully integrate into the methodological cycle.

\section{Aknowledgments}

We would like to express our warmest thanks to Dr Anna Sowińska for her support in statistical analyses of the survey results using the Mann-Whitney U test.

\section{References}

Belpaeme, T., Kennedy, J., Ramachandran, A., Scassellati, B., \& Tanaka, T. (2018). Social robots for education: A review. Science Robotics, 3(21). https://doi.org/10.1126/scirobotics.aat5954. Retrieved from: https://robotics.sciencemag.org/content/3/21/eaat5954

Bobko, K., Bubula, M., Marek, J., Sala, W., \& Wójciak, P. (2018). Programowanie i robotyka w edukacji wczesnoszkolnej. Kraków: Małopolskie Centrum Doskonalenia Nauczycieli.

Cliburn, D. C. (2006, October). Experiences with the LEGO Mindstorms throughout the undergraduate computer science curriculum. Frontiers in Education Conference, 36th Annual (pp. 1-6). IEEE (Institute of Electrical and Electronics Engineering). 
Crnokić, B., Grubišić, M., \& Volarić, T. (2017). Different applications of mobile robots in education. International Journal on Integrating Technology in Education (IJITE)6 (3). September 2017. https://doi.org/10.5121/ijite.2017.6302

Curto, B., \& Moreno, V. (2016). Robotics in education. Journal of Intelligent \& Robotic Systems, 81, 3-4. https://doi.org/10.1007/s10846-015-0314-z

Ewert, D., Schilberg, D., \& Jeschke, S. (2013). Problem-based learning of object-oriented programming with LEGO Mindstorms and leJOS. In Automation, communication and cybernetics in science and engineering 2011/2012 (pp. 315-323). Berlin-Heidelberg: Springer.

Hixon, R. (2007). Teaching software engineering principles using Robolab and Lego Mindstorms. International Journal of Engineering Education, 23(5), 868-873.

Huang, L., Varnado, T., \& Gillan, D. (2013) An exploration of robot builders' attachment to their LEGO Robots. In Proceedings of the Human Factors and Ergonomics Society, 57th annual meeting - 2013, 1825-1829.

IFR, Statistical Department. World Robotics Survey 2008.

Jolly, A. (June 17, 2014). Six characteristics of a great STEM lesson online. Retrieved from: https:// www.edweek.org/tm/articles/2014/06/17/ctq_jolly_stem.html

Khalaf, K., Balawi, S., Hitt, G., \& Radaideh, A. (2010). Innovation in teaching freshman engineering design: An integrated approach. International Conference on Education and New Learning Technologies - EDULEARN10 Proceedings, 709-720.

Klassner, F. (2002, February). A case study of LEGO Mindstorms'TM suitability for artificial intelligence and robotics courses at the college level. In ACM SIGCSE Bulletin, 34(1), 8-12.

Mitra, Manu. (2019). Robotics in education and training. Advances in Robotics \& Mechanical Engineering, 2(1), 94-96. https://doi.org/10.32474/ARME.2019.01.000126

Qureshi, M. (2019). 5 Technology Education Trends You'll See in 2019. Retrieved from: https://bsd. education/5-technology-education-trends-youll-see-in-2019/

Mubin, O., Stevens, C. J., Shahid, S. Al Mahmud, A., \& Dong, J. J. (2013). A review of the applicability of robots in education. Technology for Education and Learning. https://doi. org/10.2316/Journal.209.2013.1.209-0015

Photon Producer Web-site. https://photonrobot.com/pl

Smyrnova-Trybulska, E., Kommers, P., Morze, N., Gladun, M., \& Zuziak, W. (2017). Robotics in primary school in the opinion of prospective and in-service teachers. A comparative study. International Journal of Continuing Engineering Education and Lifelong Learning, 27(4), 318-338.

Smyrnova-Trybulska, E., Morze, N., Kommers, P., Zuziak W., \& Gladun, M. (2017). Selected aspects and conditions of the use of robots in STEM education for young learners as viewed by teachers and students. Interactive Technology and Smart Education, 14(4), 296-312. Retrieved from: http://www.emeraldinsight.com/doi/pdfplus/10.1108/ITSE-04-2017-0024

Smyrnova-Trybulska, E., Morze, N., Kommers, P., Zuziak, W., \& Gladun, M. (2016). Educational robots in primary school teachers' and students' opinion about STEM education for young learners. In P. Kommers, Tomayess Issa, Theodora Issa, E. McKay, P. Isaías (Eds.), Proceedings of the International Conferences on Internet Technologies \& Society 2016 (ITS 2016) Educational Technologies 2016 (ICEduTech 2016) and Sustainability, Technology and Education 2016 (STE 2016). Melbourne, Australia, 6-8 December, 2016 (pp. 197-204). IADIS Press.

Smyrnova-Trybulska, E., Morze, N., Zuziak, W., \& Gladun, M. (2016). Robots in elementary school: Some educational, legal and technical aspects. In E. Smyrnova-Trybulska (Ed.), E-learning methodology - Implementation and evaluation. [E-learning] 8, 321-342. Katowice-Cieszyn: University of Silesia-Studio Noa. 
Souza, I. M. L., Andrade, W. L., Sampaio, L. M. R., Araujoy, A. L. S.O. (2018). A Systematic Review on the use of LEGO® Robotics in Education (pp. 1-9). In Conference Proceedings: 2018 IEEE Frontiers in Education Conference (FIE). https://doi.org/10.1109/FIE.2018.8658751

Tokuyasu, T. (2007, May). Installation of Mechatronics Education Using the MindStorms for Dept. of Mechanical Engineering, ONCT. Mechatronics, ICM2007 4th IEEE International Conference on Mechatronics, ICM 2007 (pp. 1-5). IEEE (Institute of Electrical and Electronics Engineering).

Zaharija, G., Granić, A., \& Grubač, A. (2014). LEaRN - LEgo Robot and Netlogo. In Bože Plazibat \& Silvana Kosanović (Eds.), Conference Proceedings: Contemporary Issues IN Economy and Technology - CIET 2014. Volume: Proceedings of CIET 2014 (pp. 209-218). Split: University of Split Publishing.

Zollman, A. (2012). Learning for STEM literacy: STEM literacy for learning. School Science and Mathematics, 112(1): 12-19. https://doi.org/10.1111/j.1949-8594.2012.00101.x

Zuziak, W. (2014). Teaching how to code we teach through the coding. In E. Smyrnova-Trybulska (Ed.), E-learning and intercultural competences development in different countries (pp. 371-381). Katowice-Cieszyn: University of Silesia, Studio Noa.

Zuziak, W. (2013). Designing and programming robots in contemporary didactics in Polish Schools In E. Smyrnova-Trybulska (Ed.), E-learning \& Lifelong Learning, 5, 497-509.

Zuziak, W. (2015). Creatively and informally: Scratch and the remix culture. International Journal of Research in E-learning, 2, 89-105.

Eugenia Smyrnova-Trybulska, Dawid Staniek, Dominika Zegzuła

\title{
Robotyka w edukacji w opinii uczniów Raport $\mathrm{z}$ ankiety: studium przypadku
}

\author{
Streszczenie
}

W artykule dokonano analizy różnych aspektów zastosowania robotyki w edukacji oraz przedstawiono poziom przygotowania i motywacji dzieci i uczniów. Autorzy przeprowadzili kompleksowy przegląd publikacji naukowych dotyczących technologicznych, dydaktycznych, metodologicznych i ludzkich aspektów wykorzystania robotyki w edukacji. W artykule przedstawiono raport z badania opinii uczniów na temat robotyki w edukacji. Badanie przeprowadzono podczas trzeciego Śląskiego Festiwalu Nauki, dlatego artykuł opisuje również stoisko festiwalowe prezentujące „Innowacyjne technologie i metody cyfrowe w edukacji i biznesie" oraz roboty Photon.

S łow a kluc z ow e: roboty, roboty edukacyjne, robotyka w edukacji, edukacja STEM, ankieta 
Eugenia Smyrnova-Trybulska, Dawid Staniek, Dominika Zegzuła

\title{
Робототехника в образовании: мнения учащихся Тематическое исследование
}

\begin{abstract}
Анногтация
В данной статье анализируются различные аспекты использования робототехники в образовании, а также анализируется уровень подготовки и мотивации детей и школьников. Авторы проводят всесторонний обзор научных публикаций, касающихся технологических, дидактических, методологических и гуманитарных аспектов использования робототехники в образовании. В статье представлен отчет об опросе учеников о робототехнике в образовании, который был проведен во время третьего Силезского научного фестиваля, а также показан стенд выставки, на котором представлены экспонаты «Инновационные цифровые технологии и методы в образовании и бизнесе» и роботы Фотоны (Photon).

К л ю ч е в ы е с л о в а: роботы, образовательные роботы, робототехника в образовании, STEM образование, опрос
\end{abstract}

Eugenia Smyrnova-Trybulska, Dawid Staniek, Dominika Zegzuła

\section{Robótica en la educación: en la opinión de los alumnos Informe de encuesta: un estudio de caso}

\author{
Resumen
}

Eeste artículo analiza varios aspectos del uso de la robótica en la educación y examina el nivel de preparación y motivación de niños y alumnos. Los autores llevan a cabo una revisión exhaustiva de investigaciones y publicaciones científicas sobre aspectos tecnológicos, didácticos, metodológicos y humanos del uso de la robótica en la educación. El artículo presenta un informe sobre una encuesta sobre la opinión de los alumnos sobre Robótica en educación que se realizó durante el tercer Festival de Ciencia de Silesia, y discute el stand de exhibición que presenta "Tecnologías y métodos digitales innovadores en educación y negocios" y Robots Photon.

P a la bras c lave: Robots, robots educativos, Robótica en educación, educación STEM, encuesta.

IJREL.2020.6.1.08 p. 18/18 